\title{
Free-Market, Perfect Market and Welfare State Perspectives on "Good" Markets: an Empirical Test
}

\author{
Johan Graafland ${ }^{1}$ (D) $\cdot$ Harmen Verbruggen ${ }^{2}$
}

Received: 9 November 2020 / Accepted: 30 March 2021/Published online: 20 May 2021

(C) The Author(s) 2021, corrected publication 2021

\begin{abstract}
This study explores the relationship between human development and market institutions and tests the performance of three alternative economic perspectives that each assign a different role to governments. In the free-market perspective, the principal task of the government is to protect property rights. In the perfect-market perspective, the government has the additional responsibility of correcting market failures. The welfarestate perspective posits that the state must actively adopt welfare-state policies across a broad range of fields. Based on a sample of 34 OECD countries plus Russia across a time frame spanning 1990 to 2018, the results demonstrate that economic freedom and small size of government do not significantly affect human development as measured by the Human Development Index. Hence, we find no support for the free-market ideal. Conversely, it is found that human development is positively related to governmental interventions that aim to reduce externalities (public expenditure on education and environmental regulation). These results support the perfect-market perspective. With respect to the welfare-state perspective, the findings are mixed. On the one hand, we found that (some) labor market regulations (particularly hiring and firing regulations, hours regulations and mandated cost of worker dismissal) have a negative impact upon human development. On the other hand, human development is shown to be positively affected by governmental intervention seeking to reduce gender stratification in the labor market.
\end{abstract}

Keywords Economic freedom · Human development - Free-market perspective . Neoliberalism $\cdot$ Perfect-market perspective $\cdot$ Welfare state

Johan Graafland

j.j.graafland@uvt.nl

Harmen Verbruggen

h.verbruggen@vu.nl

Extended author information available on the last page of the article 


\section{Introduction}

A perennial debate in economics is what should be left up to the market, and in what circumstances, as well as to what extent, governments should intervene to ensure the well-being of their citizens. In this study, we distinguish between three different economic perspectives on what role the government should play in market processes. Firstly, at one end of the spectrum, we examine the free-market perspective, according to which the smaller and less-interventionist a government is, the less likely the freedom of economic agents to pursue their own trade-offs and preferences will be substituted by governmental decision-making. From the free-market perspective, markets require as a conditio sine qua non solid foundations, such as property rights, contract security, legal certainty and protection against aggression. This has to be guaranteed by a minimal state. Secondly, there is the perfectly competitive market perspective, or shortly, the perfect-market perspective. In this perspective, the ideal of economic policy is a perfectly competitive market economy. A free-market with a minimal state is not a well-functioning (perfect) market per se, and, as such, it is the responsibility of the government to intervene and correct for market failures (Sandmo, 2011). Some of the most important of these failures are positive and negative external effects, as well as the lack of competition that inhibits a well-functioning and market clearing price mechanism. Thirdly, at the other end of the spectrum, the welfare-state model accords the government a leading role, namely in terms of managing effective demand and providing social security to smooth the sharp edges of the free market. The degree of cross-country diversity in market institutions is evidenced by the extensive body of literature on the manifold iterations of capitalism (Hall \& Gingerich, 2009; Hall \& Soskice, 2001; Whitley, 1999; Witt et al., 2018).

These three perspectives are inspired by, and, indeed, have their lineage in, three distinct theoretical systems, as well as their attendant policy recommendations and accompanying market institutions. These distinct schools of economic thought about the balance between the market and governments are the Neoliberal, Neoclassical and Keynesian perspectives (see below).

Clearly, all three of these perspectives strive for the economic betterment of people, albeit in different ways. In this study, we set out to empirically test how the policies recommended by the three concurrent perspectives contribute to human development. To the best of our knowledge, there have hitherto been no studies that have empirically tested how "good" the different economic perspectives are in terms of contributing to human development. The question posed in this study is: Which particular composition of market institutions constitutes a "good" market economy that contributes to human development? This question has received renewed attention in recent years due, in part, to a nascent awareness that the traditional form of capitalism, that is, the free-market perspective, may in fact undermine the good life (Skidelsky \& Skidelsky, 2012). Of course, there is considerable debate about how to define and measure the "good life" that the market economy is ostensibly aiming towards. Most previous research on economic institutions has used GDP per capita as a measure of good economic performance. Undoubtedly, GDP per capita does provide relevant information about the quality of life in a given country. Indeed, improved living standards not only provide a direct indication of material dimensions of well-being, but they are also an important pre-condition for other types of well-being, such as the level of health and 
leisure time (Ruseski \& Maresova, 2014) and life satisfaction (Di Tella et al., 2003). Despite this, Stiglitz et al. (2009) and Layard (2005) have argued that GDP per capita has several shortcomings in terms of serving as an effective proxy for well-being.

In this study, we use human development as delineated in the human development index (HDI) (UNDP, 2020) as a measure of the good life. The HDI captures three essential components of human development: a long and healthy life; access to knowledge; and a decent standard of living. Because of the inclusion of information on health and education, the HDI provides a more complete measure of overall development than GDP per capita (Özcan \& Bjørnskov, 2011). Through recourse to Sen's (1984) capability approach, the HDI attempts to track people's capacity to exercise their freedom in the pursuit of a better life. Although the HDI does not account for other important dimensions of a good human life, such as life satisfaction, housing, community, environment and civic engagement, it is nevertheless the best measure in terms of both allowing for a comparison of a large number of countries over a long period of time (Nikolaev, 2014), and being a better predictor of other dimensions of the good life than GDP per capita. ${ }^{1}$

The paper is structured as follows. First, we elucidate what market institutions are considered to be 'good' in relation to the three distinct perspectives. Section 3 outlines the methodology that underpins the empirical test, including the model specification, data sources and measurement of variables. In Section 4, we present the results of the empirical analysis. Section 5 provides a cross-country analysis that relates human development to those institutional characteristics that were found to have a significant influence on human development. Section 6 concludes with a summary of the findings, and a discussion of the policy implications of the study.

\section{Three Economic Perspectives on "Good" Markets}

The notion that freely operating markets are conducive to social welfare is wellestablished in economics. In fact, it can be understood as one of the central tenets of economics, which dates back to Adam Smith's Wealth of Nations. It is also generally acknowledged that free markets cannot operate in a vacuum, but rather must be backed and facilitated by the government. Here, the question of both the appropriateness and the extent of governmental intervention in a market economy engenders a broad spectrum of opinions and political practices, which, in turn, are manifested in concrete practices. This study takes recourse to three different schools of economic thought to describe the perspectives and disentangle the sources of human development, namely (1) the Neoliberal school, (2) the Neoclassical school, and (3) the welfare-state school.

\section{The Free-Market Perspective}

Neoliberalism is a rather vague and often highly contested concept. Thorsen (2009) purports that Neoliberalism is a loose set of ideas pertaining to how the relationship between the government, individuals and the market ought to be organised, which, in

\footnotetext{
${ }^{1}$ For an empirical analysis of the relationship between human development and various dimensions of the quality of life as measured by the OECD Better Life Index, see Appendix Table 7.
} 
turn, links to a heterogeneous set of political theories. In one of the first titles referring to the concept (Cros, 1950), Neoliberalism is described as the political ideology of neoAustrian theorists, who aimed to reinvigorate the classical liberalism of Locke and Smith (Ryan, 1993). Ver Eecke (1982) defined Neoliberalism as a particular kind of liberalism, which is marked by a deep-seated commitment to laissez-faire economic policies. As well as neo-Austrians such as Mises, Hayek and Schumpeter, it also refers to monetarists and other economists, such as Friedman (1962), who defend 'free markets'.

Notwithstanding the diversity of its usage in political theory, Neoliberalism does have a clear view on economic institutions. Specifically, it proposes that human wellbeing can best be advanced by liberating individual entrepreneurial freedoms and skills within an institutional framework characterised by strong private property rights, free markets and free trade (Harvey, 2005). According to Schumpeter (1976), the fundamental impulse that sets and keeps the capitalist engine in motion is new consumer goods, new methods of production or transportation, new markets and new forms of industrial organisation that capitalist enterprise generates, rather than competition over who can offer the lowest price at any given point in time. Such (monopolistic and oligopolistic) competition is not only more common than perfect competition, but it is also believed to be much more effective in terms of expanding output in the long-term and reducing prices. In contrast, perfect competition solely yields short-term wealth creation (as a result of lower prices), and, as such, is inferior insofar as it limits the potential of a company to engage in a long-term strategy of price and process development. In the field of international trade, free exchange rates and free trade are favoured.

The organisation of the free-market economy through voluntary exchange presupposes a legal framework capable of ensuring that one person cannot coerce another, that contracts are enforced, and that the meaning of property rights is defined, interpreted appropriately and enforced when needed. These aforementioned matters should be guaranteed by the government, because "the role of government is just considered to be something that the market cannot do for itself, namely, to determine, arbitrate, and enforce the rules of the game" (Friedman, 1962: 27). In addition to this, the government must also provide military, police and courts as public goods.

The government should refrain from intervening in the economic sphere via macroeconomic policy, industrial policy, or price and wage policy. The government must simply guarantee the quality and integrity of money, as opposed to adopting monetary or budgetary policies to stabilize the economy. Active regulation is considered to be counterproductive, because the government has limited information and no incentive to take advantage of the available opportunities. "Competition must be seen as a process in which people acquire and communicate knowledge; to treat it as if all this knowledge were available to any one person at the outset is to make nonsense of it" (Hayek, 1979: 68). According to Hayek, we can never have complete knowledge of the circumstances, neither at the individual or societal level. Hence, decisions should be decentralised as much as possible to people who know the circumstances and can foresee the requisite changes, which can then be anticipated with the available resources. Even in the sphere of public goods provision and the correction of market imperfections (externalities), government action should be limited, because of both the high likelihood of government failure and the distortions it creates in the market process. Stigler (1971) 
forcefully argued that regulation is wanted by the industry and is designed and operated primarily for its benefit. In many cases, the government is simply unable to correct recognised market failures (Harvey, 2005). The argument here is that such failures stem from, among other things, asymmetric information, failing to put the public interest first (instead prioritising the interests of various lobby groups), self-seeking bureaucrats and a lack of human and financial resources.

Finally, proponents of free-market economics espouse that in their preferred market form there is simply no place for a social safety net, except at a bare minimum, and income redistribution policies. In contradistinction to the government, economic agents are assumed to be knowledgeable and sufficiently rational to make their own trade-offs at the right time and take care of themselves. The adoption of a minimal state would thus foster an environment in which markets would flow by themselves completely undisturbed, in such a way that would deliver the desired welfare-enhancing outcomes, while, simultaneously, guaranteeing individual rights and freedoms (Chang, 2014).

\section{The Perfect-Market Perspective}

Neoclassical economics dominates the mainstream of economic science. The ideal in Neoclassical economics (Marshall, 1920; Pigou, 1932) is the perfect market that is free from market imperfections. In this perspective, the basis of economic growth is a wellfunctioning price mechanism that coordinates the decisions of various economic subjects (CPB, 1992). The level of prosperity depends on the available production factors (natural resources, quantity and quality of the labor supply, and size of capital stock) and the state of technology. The level of saving determines the growth of the capital stock. Research and development (R\&D) and investments in human capital are also major growth determining factors, which derive from the optimal choices of companies and households. As a result of free trade, countries specialise in products that they have a comparative advantage in, while international trade provides opportunities for exploiting economies of scale (Baldwin, 1992).

Here, the role of the government is modest and strictly limited to the production of pure public goods (such as defense, infrastructure and justice) and combating market imperfections. It is well established in Neoclassical economics that markets can fail. Marshall, who is widely credited with inventing the concept of external effects (Sandmo, 2011), suggested that one ought to tax negative externalities and use the revenue to subsidise positive externalities (Marshall, 1920, p. 472-3). Examples of negative external effects include greenhouse gas emissions that cause climate change, local air pollution, soil and water pollution, and ecosystem degradation (Baumol \& Oates, 1988; Jacobs, 1997). One notable example of a positive externality that receives insufficient provision is education. In addition to private rewards, education has the external effect of raising the quality of the labor force and hence productivity and economic growth. Subsequently, Pigou (1932) elaborated on the difference between social and private marginal costs and benefits deriving from external effects, as well as showing that competitive markets can produce inefficient levels of output. According to Pigou, the principal welfare task of governments is to equalise private and social marginal costs and benefits via taxes and subsidies associated with legal regulation. However, Coase (1960) demonstrated that government regulation is not necessarily needed, if there are corresponding property rights in place. Having said this, this finding 
only holds if the transaction costs are negligible. In many real-world cases, large numbers of people are affected by external effects, and, hence, government intervention may be more optimal than market-based negotiations.

There is some place for governments to implement active labor market policies or provide collective social insurance within the Neoclassical perspective, but only insofar these policies correct for market imperfections. As neoclassical economics assumes humans are rational and capable of making their own choices, it allows little room for additional labor market regulations. Neoclassical economists, for example, posit that unemployment, or, at the very least, some degree of unemployment, is voluntary and a structural feature of equilibrium (Boyer \& Smith, 2001). Nevertheless, the government may opt to correct the income distribution that results in market equilibrium, in order to assist those who are unable to earn a sufficient income. This is a political decision that depends on the political trade-off between efficiency and equity.

\section{The Welfare-State Perspective}

The third perspective is grounded in the thought of Keynes and Beveridge. Keynes (1936) argued that the future is fundamentally uncertain, which, in turn, provides space for fluctuations in expectations (animal spirits) that are both self-fulfilling and cumulative. In this approach, markets are not self-correcting (Blaug, 1978). These uncertainties and fluctuations also negatively impact on long-term economic growth, as a result of their detrimental effects on human and physical capital formation (Blanchard $\&$ Fischer, 1992). Consequently, the atomistic pursuit of private interest may fail to engender stable economic development. In order to achieve economic development, some degree of cooperation and coordination by the government is instead required. Hence, the government should pursue active anti-cyclical policies and support employment creation. To reduce uncertainty, market regulations, industrial policies and coordinated decision-making in strategic projects with potential long-term gains for national welfare are required. In the field of international trade, the desire to reduce uncertainty leads to the preference for government controlled exchange rates and trade policies (quotas, import tariffs, qualitative restrictions, export subsidies, R\&D subsidies for emerging industries) as a means of correcting potentially myopic entrepreneurs or protecting against a volatile global market or aggressive foreign competition. ${ }^{2}$

Although Keynes observed the curse of unemployment, he was not initially interested in social policy. The major breakthrough in welfare-state economics came with the publication of the Beveridge (1942) report. Beveridge sought and received assistance from Keynes, subsequently becoming a convert of Keynesianism, despite rejecting his plea for protectionism. Keynes supported Beveridge's plan to extend social security benefits and contributions to the entire population, albeit he was concerned about the budgetary implications of doing so. In a letter to Beveridge on 14 October 1942, Keynes referred to Beveridge's plan as a grand document and hoped that its key components would be adopted (Marcuzzo, 2010: p. 202). ${ }^{3}$ In the welfarestate perspective, there is a potentially extensive role for the government to correct the

\footnotetext{
${ }^{2}$ At the economic advisory council's committee of economists, Keynes made a plea for protectionism to reduce unemployment (Marcuzzo, 2010).

${ }^{3}$ The welfare state also came to be embraced by the post-Keynesian school, at the initiation of Joan Robinson.
} 
myopia of economic agents (Berggren \& Bjørnskov, 2019; Brue \& Grant, 2007). In light of this, the government may, depending on the political constellation, also wish to correct the outcome of free-market processes out of a desire for greater equality in income distribution. The ideology of the welfare state is predicated on the notion that, in order to advance individual freedom, the state must adopt an active role in implementing social reform. This motivates a broad range of welfare-state policies in health care, social insurance and assistance, housing, public transportation, minimum wage legislation and the redistribution of income through a progressive tax system. The principal objectives of a welfare state are to boost living standards and reduce inequality (Marcuzzo, 2010). The welfare-state perspective is predicated on the notion of inclusive economic growth. According to Keynes, his general theory should provide for full employment and "... reduce [the] arbitrary and inequitable distribution of wealth and income" (Keynes 1936, 1973, p. 372). In this perspective, government regulations that aim to correct gender inequities in the labor market via the introduction of gendered welfare-state provisions are also justified (Terjesen et al., 2015). ${ }^{4}$

\section{Implications for Government Institutions}

Table 1 summarises the policy preferences of the three schools of thought with respect to specific indicators of government institutions.

The free-market perspective has been operationalised in Gwartney et al.'s (1996) concept of economic freedom, along with being defined in measurable indicators by the Fraser Institute's Economic Freedom of the World Index (Fraser-EFW index, see https://www.fraserinstitute.org/economic-freedom/approach). According to this definition, individuals have economic freedom when property rights are secure and when they are free to use, exchange or give their property to another, provided their actions do not violate the identical rights of others. Friedman, among others, was involved in the creation of this index. This index consists of 44 indicators which are grouped into five sub-constructs of economic freedom:

- small government (low general government consumption, low government transfers and subsidies, no government enterprises and investment and low top marginal tax rate);

- rule of law (protection of property rights, enforcement of contracts, independent judiciary, and an impartial court system);

- sound monetary policy (low money growth, low standard deviation of inflation, low inflation in the most recent year, freedom of citizens to own foreign currency bank accounts);

- freedom to exchange goods and services internationally (absence of tariffs, quotas, hidden administrative restraints, and exchange rate and capital controls);

- freedom from government regulation of credit, labor, and product markets. As we want to test the effects of small government and labor market regulation on human development separately, we excluded these two elements from the measure of economic freedom.

\footnotetext{
${ }^{4}$ As a reviewer suggested, the gender board variable can also be conceived as a proxy for more positive gender attitudes in general.
} 
Table 1 Policy preferences of different schools

\begin{tabular}{|c|c|c|c|c|c|c|}
\hline \multirow{3}{*}{$\begin{array}{l}\text { Schools } \\
\begin{array}{r}\text { Institutional } \\
\text { indicators }\end{array}\end{array}$} & \multicolumn{6}{|c|}{ From less to more government intervention } \\
\hline & \multicolumn{2}{|c|}{ Free-market perspective } & \multicolumn{2}{|c|}{$\begin{array}{l}\text { Perfect-market perspective } \\
\text { Welfare-state perspective }\end{array}$} & \multicolumn{2}{|c|}{ Welfare-state perspective } \\
\hline & $\begin{array}{l}\text { Economic } \\
\text { freedom }^{\mathrm{a}}\end{array}$ & $\begin{array}{l}\text { Small } \\
\text { government }\end{array}$ & $\begin{array}{l}\text { Public } \\
\text { education } \\
\text { expenditure }\end{array}$ & $\begin{array}{l}\text { Environmental } \\
\text { regulation }\end{array}$ & $\begin{array}{l}\text { Labor } \\
\text { market } \\
\text { regulation }\end{array}$ & $\begin{array}{c}\text { Gender labor } \\
\text { market } \\
\text { policies }\end{array}$ \\
\hline
\end{tabular}

${ }^{a}$ Excluding small government and labor market regulation

The perfect-market school partially supports the notion of economic freedom espoused by the free-market school, insofar as its adherents believe that the market is largely able to self-regulate. It also stresses the need for protecting property rights, sound monetary policy and free trade. However, in contrast to the free-market school, Neoclassical economists argue that the government has a vital role to play in correcting positive externalities (for example, via public education expenditure) and negative externalities (for example, via environmental regulation). This implies that Neoclassical economists adopt an intermediate stance vis-à-vis government regulation.

Like the free market and perfect-market school, the welfare state school supports the importance of rule of law (protection of property rights). But when it comes to the other dimensions of economic freedom, the welfare-state school lies at the opposite end of the spectrum in comparison to the free-market perspective. First, the welfare-state perspective endorses institutions that redistribute income and therefore supports a progressive tax system. This implies that the welfare-state perspective opposes a small government (which includes low marginal income tax rate as a measure of low progressivity of the tax system). Furthermore, whereas free-market economists believe that government intervention in markets should be minimal, welfare-state economists see it as essential that governments provide social insurance and assistance. Second, similarly to the Neoclassical school, it stresses the need for education policies and environmental regulation, but when it comes to labor market regulation, their view on structuring labor markets is in contradistinction to both the Neoclassical and Neoliberal position that higher levels of labor market regulation is ultimately inefficient, particularly the regulations in Fraser Institute's measurement that shield insiders from competition from outsiders (e.g. hiring and firing regulations and mandated cost of worker dismissal) (Blanchflower et al., 1990; Flanagan, 1988; Lindbeck \& Snower, 1986, 1987; Pissarides, 1990).

\section{Methodology}

\section{Model Specification}

In order to address the research question of what constellation of market institutions constitutes a "good" market, the following model was tested: 


$$
\begin{aligned}
\mathrm{HDI}_{\mathrm{i}, \mathrm{t}}= & \alpha_{0}+\alpha_{1} \mathrm{EF}_{\mathrm{i}, \mathrm{t}-5}+\alpha_{2} \mathrm{SG}_{\mathrm{i}, \mathrm{t}-5}+\alpha_{3} \mathrm{PEE}_{\mathrm{i}, \mathrm{t}-5}+\alpha_{4} \mathrm{EP}_{\mathrm{i}, \mathrm{t}-5}+\alpha_{5} \mathrm{LR}_{\mathrm{i}, \mathrm{t}-5} \\
& +\alpha_{6} \mathrm{GR}_{\mathrm{i}, \mathrm{t}-5}+\sum \beta_{\mathrm{k}} \mathrm{X}_{\mathrm{i}, \mathrm{k}, \mathrm{t}}+\sum \gamma_{\mathrm{n}} \mathrm{D}_{\mathrm{i}, \mathrm{n}}+\varepsilon_{\mathrm{i}, \mathrm{t}}
\end{aligned}
$$

$$
\mathrm{EP}_{\mathrm{i}, \mathrm{t}}=\delta_{0}+\delta_{1} \mathrm{EF}_{\mathrm{i}, \mathrm{t}-5}+\delta_{2} \mathrm{ER}_{\mathrm{i}, \mathrm{t}-5}+\sum \lambda_{\mathrm{k}} \mathrm{X}_{\mathrm{i}, \mathrm{k}, \mathrm{t}}+\sum \mu_{\mathrm{n}} \mathrm{D}_{\mathrm{i}, \mathrm{n}}+\varepsilon_{\mathrm{i}, \mathrm{t}}
$$

HDI denotes the human development index, EF economic freedom (excluding SG and LR), SG (small) size of the government, PEE public expenditure on education, EP environmental pollution, ER environmental regulation, LR labor market regulation, GR gender regulation, $\mathrm{X}$ time-variant control variables, $\mathrm{D}$ time-invariant country variables, and $\varepsilon$ the residual. The index i denotes the country and $t$ denotes the year. We included political rights, urbanisation, and percentage of labor in industry as our time-variant control variables (Ovaska \& Takashima, 2006; Bennett \& Nikolaev, 2017; Feldmann, 2017). The set of time-invariant control variables depends on the estimation technique, as we estimated both fixed effects and random effects models. The fixed effects model included country fixed effects; in the random effects model we included seven timeinvariant control variables. First, for our geographical variables, we used the log of great circle air distance as a measure for market access difficulties in global and regional trade flows (Mayer \& Zignago, 2011), (no) access to sea (landlocked), and average annual temperature as an indicator of climate (Bjørnskov et al., 2008). Second, we included a dummy for post-communist countries. Third, a dummy for monarchy was included as a unifying factor that can positively affect well-being (Bjørnskov et al., 2008). Finally, we added religion as a control variable, distinguishing between the percentage of Christian, Muslim and Non-religious people.

The model differs in one respect from the framework outlined in Section 2.4, as eq. (1) uses environmental pollution as an explanatory variable rather than environmental regulation. The reason for this is that the effect of environmental regulations on human development is rather indirect and often takes a long period of time to materialise. Therefore, we added eq. (2) and proceeded on the assumption that environmental regulation reduces environmental pollution, which, in turn, affects human development (particularly life expectancy as a result of better air quality). ${ }^{5}$

In order to test for fixed versus random effects, we performed the standard Hausman test. Whereas the fixed effects model controls for endogeneity resulting from correlation between explanatory variables and the time invariant country-specific individual effects, it does not solve biases that result from possible correlation between explanatory variables with the idiosyncratic random disturbance term. Economists have tried solving these problems by using time variant instrumental variables for institutional variables (Tabellini, 2010), but the exclusion restriction remains problematic. In order to reduce the chance of simultaneity bias, we followed Bennett and Nikolaev (2017) and used for all institutional variables five-year lagged values. However, we must bear

\footnotetext{
${ }^{5}$ Another reason for adding equation (2) is that the overlap in the sample of environmental regulation and the sample of all variables in equation (1) is rather small. The overlap in data of environmental regulation and environmental pollution is much larger. Replacing environmental pollution by environmental regulation in equation (1) would therefore substantially reduce the number of observations.
} 
in mind that using lags is not really satisfactory in solving the problem of endogeneity or simultaneity bias, as t-5 may be correlated with performance in $\mathrm{t}$. Still, as we will argue below, the results indicate that the estimated coefficients are very likely to represent causality running from institutions to human development rather than reverse.

Furthermore, since the White test indicated heteroscedasticity, we used robust standard errors for the calculation of the significance of the regression coefficients. All variables were standardised prior to estimating the equations. For all regressions, we calculated the Variance Inflation Factor in order to check for multicollinearity. The maximum value was always around 2.5 or lower, and thus well below the critical value of 10. Finally, we tested for stationarity of the residuals of the regression analysis, using the Fisher-test (one of the few cross-sectionally augmented Dickey-Fuller statistic that is applicable to an unbalanced sample) (Pesaran, 2007). The null hypothesis of this test is that a panel variable (v) contains a unit root (e.g. $\alpha=1$ in $\left.v_{t}=\alpha v_{t-1}+\varepsilon_{t}\right)$.

\section{Data Sources}

Based on the available data, we created a sample of 34 OECD countries plus Russia ${ }^{6}$ spanning across the period 1990 to 2018 . Table 2 presents the statistics for the variables.

The nature of the panel is unbalanced due to the fact that data was not available for the full sample of countries over the entire period under consideration. Furthermore, although the sample predominantly consists of OECD countries, the variables show nonetheless substantial variance among countries.

As aforementioned, it is difficult to capture the full scope of human development in a single indicator that would serve as the dependent variable. Ultimately, we opted for the (2010 definition of the) HDI of the UN, on the basis of its coverage and the availability of data. The HDI is a composite measure consisting of the average achievements of each country in relation to key dimensions of human development, namely standard of living (consisting of the logarithm to Gross National Income per capita), a long and healthy life (measured by life expectancy at birth), and education (measured by a combination of the adult literacy rate and school enrolment ratios). The HDI is a geometric mean of the normalised indices for each one of these three dimensions of human development. We used three-year averaged observations of HDI to isolate business cycle influences on income per capita (Polemis \& Stengos, 2020).

Following the literature on economic freedom, we used the Fraser-EFW index as a measure of economic freedom (Gwartney et al., 2017). It contains five sub dimensions (see section 2.4). Within these five major areas, there are 25 components in the index. Many of those components are themselves made up of several sub-components. In total, the index comprises 44 distinct variables. Each component and sub-component is placed on a scale from 0 to 10 , which reflects the distribution of the underlying data, on a range from least free to most free. When subcomponents are present, the subcomponent ratings are averaged to derive the component rating. The component ratings within each area are then averaged to derive ratings for each of the five areas. We used the overall index of economic freedom, corrected for the two sub-dimensions of government size and government regulation of the labor market, as we used these as separate explanatory variables in the theoretical framework in section 2 .

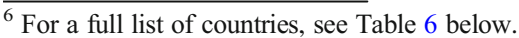


Table 2 Complete list of measures, descriptive statistics, and sources, 1990-2018

\begin{tabular}{|c|c|c|c|c|c|c|}
\hline & $\mathrm{N}$ & Mean & SD & Min & Max & Source \\
\hline Human development index & 1013 & 0.84 & 0.07 & 0.58 & 0.95 & $\mathrm{UN}^{\mathrm{e}}$ \\
\hline Income per capita index & 1015 & 0.86 & 0.07 & 0.64 & 1.00 & UN \\
\hline Education index & 1013 & 0.78 & 0.10 & 0.40 & 0.95 & $\mathrm{UN}$ \\
\hline Life expectancy index & 1015 & 0.88 & 0.06 & 0.68 & 0.99 & UN \\
\hline Economic freedom index & 554 & 7.45 & 1.74 & 3.05 & 9.26 & Fraser Institute \\
\hline (Small) size of government index & 630 & 6.27 & 1.22 & 3.49 & 9.46 & Fraser Institute \\
\hline Public education expenditure ( $\%$ of GDP) & 703 & 5.19 & 1.20 & 1.93 & 8.56 & World Bank \\
\hline Environmental pollution ${ }^{\mathrm{a}}$ & 912 & 1.21 & 1.60 & 0.01 & 12.17 & OECD \\
\hline Environmental regulation index & 604 & 1.74 & 0.92 & 0.21 & 4.13 & OECD \\
\hline Labor regulation index ${ }^{\mathrm{b}}$ & 560 & 3.46 & 1.20 & 1.16 & 6.19 & Fraser Institute \\
\hline Gender regulation index & 1015 & 0.002 & 0.03 & 0.00 & 0.40 & Terjesen et al. \\
\hline Political Rights index ${ }^{c}$ & 1003 & 6.73 & 0.86 & 1 & 7 & Freedom House \\
\hline Urbanisation $^{\mathrm{d}}$ & 1015 & 75.31 & 11.29 & 47.92 & 98.00 & World Bank \\
\hline Labor share industry & 980 & 26.40 & 5.98 & 10.60 & 44.56 & World Bank \\
\hline Great circle air distance index & 1015 & 3.81 & 1.66 & 0.40 & 6.40 & CEPII database \\
\hline Landlocked (dummy) & 1015 & 0.17 & 0.38 & 0 & 1 & \\
\hline Temperature (in ${ }^{\circ} \mathrm{C}$ ) & 1015 & 8.09 & 6.04 & -7.14 & 21.51 & Wheatherbase \\
\hline Post-communist (dummy) & 1015 & 0.23 & 0.42 & 0 & 1 & \\
\hline Monarchy (dummy) & 1015 & 0.31 & 0.46 & 0 & 1 & Wikipedia \\
\hline Christian (\% of population) & 1015 & 0.69 & 0.26 & 0.00 & 0.95 & PEW \\
\hline Muslim (\% of population) & 1015 & 0.06 & 0.16 & 0.00 & 0.98 & PEW \\
\hline Non-religious (\% of population) & 1015 & 0.21 & 0.17 & 0.01 & 0.76 & PEW \\
\hline
\end{tabular}

${ }^{a}$ Emissions of air pollutants (in thousands of tonnes) per capita

${ }^{\mathrm{b}}$ Measured as 10 - freedom from labor market regulation

${ }^{\mathrm{c}}$ Redefined as ranging from the lowest (1) to the highest (7) score

$\mathrm{d}$ Percentage of population living in urban areas

${ }^{\mathrm{e}} \mathrm{https}$ ://globaldatalab.org/shdi/incindex $/$ ?levels $=1 \% 2 \mathrm{~B} 4$ \& interpolation $=0$ \&extrapolation $=0$ \&nearest_real $=0$

The Fraser-EFW sub-index for government size includes (1) government consumption, as percentage of total consumption, (2) transfers and subsidies as percentage of GDP, (3) government investment as percentage of total investment, (4) top marginal income (payroll) tax rate, and (5) state ownership (the degree to which the state owns and controls capital (including land) in the industrial, agricultural, and service sectors). The component 'Transfers and subsidies' indicates to what extent social welfare programmes are financed by taxing “... some people in order to provide transfers to others". ${ }^{7}$ The larger the government size, the lower the Fraser-EFW sub-index for SG,

\footnotetext{
${ }^{7}$ An alternative measure of spending levels of government expenditure is the so-called decommodification, which reflects the possibility for citizens to freely opt out of work, when necessary, without risking their jobs, incomes, and general welfare (Pacek \& Radcliff, 2008). Decommodification measures the easiness of access to welfare benefits, their income-replacement values, and the expansiveness of coverage across different statuses and circumstances. Flavin et al. (2014) found that decommodification increases life satisfaction. Pacek and Radcliff (2008) found a similar result, but also found that decommodification decreases happiness.
} 
as government expenditure and income distort economic freedom. The Fraser-EFW index 'Labor market regulation' comprises a number of sub-components characteristic of a sheltered labor market: minimum wage, hiring and firing regulations, centralised collective bargaining, hours regulations, mandated cost of worker dismissal, and conscription. $^{8}$ For the sub-index of labor market regulation, we used the complement (11 - the score of Fraser Institute), as in Fraser's methodology countries with high (low) labor market regulation receive a low (high) score. For public education expenditure, we used government expenditure on education as a percentage of GDP of the World Bank. For environmental regulation, we used the OECD environmental policy stringency index. This stringency index is defined as the degree to which a government's environmental policies put a price, explicitly or implicitly, on polluting and environmentally harmful behaviours. For the quality of the local environment, air pollution in particular is a strong indicator of an environmental externality. Data on local air pollution came from the same OECD database on air and climate. We used threeyear averaged observations to isolate business cycle influences (Polemis \& Stengos, 2020). For gender regulation, we used legal gender board quotas, i.e. the legal minimum for the share of women who are on boards (average of publicly traded and state-owned enterprises). (Terjesen et al., 2015).

\section{Results}

\section{Bivariate Correlation Analysis}

Table 3 reports the results of the bivariate correlation analysis of the dependent and independent variables.

Human development (HDI) is positively related to economic freedom (EF), public education expenditure (PEE), environmental regulation (ER) and gender regulation (GR), and is negatively related to (small) government size (SG), labor market regulation (LR) and environmental pollution (EP). Environmental pollution is negatively related to environmental regulation. This suggests that the causality runs from environmental regulation to environmental pollution, as more regulation would lead to less pollution. If the causality would be reverse and environmental regulation came about when there was greater pollution, one would expect a positive sign.

\section{Regression Analysis}

Table 4 reports the results of the multiple regression analysis. Columns 1-2 present the results for the regression results for the HDI and columns 3-4 for environmental pollution. Both for HDI and environmental pollution, the estimation results for the random effects (RE) and fixed effects (FE) models are very similar and it is therefore not surprising that the Hausman test is insignificant. Based on this result, we prefer the

\footnotetext{
${ }^{8}$ Note that the Fraser Institute's labor market regulation index does not capture all labor regulations. Examples of regulations that are missing are occupational regulations (health and safety standards, job qualifications), gender regulations, and child labor laws. Furthermore, a reviewer noted that conscription is not generally perceived as a labor market regulation.
} 
Table 3 Bivariate correlation analysis ${ }^{\mathrm{a}}$

\begin{tabular}{|c|c|c|c|c|c|c|c|c|c|c|c|}
\hline & & 1 & 2 & 3 & 4 & 5 & 6 & 7 & 8 & 9 & 10 \\
\hline 1 & $\mathrm{HDI}^{\mathrm{b}}$ & 1 & & & & & & & & & \\
\hline 2 & Income $^{b}$ & 0.88 & 1 & & & & & & & & \\
\hline 3 & Education $^{\mathrm{b}}$ & 0.83 & 0.55 & 1 & & & & & & & \\
\hline 4 & Life expectancy ${ }^{\mathrm{b}}$ & 0.77 & 0.72 & 0.35 & 1 & & & & & & \\
\hline 5 & Economic freedom ${ }^{\mathrm{c}}$ & 0.67 & 0.71 & 0.54 & 0.40 & 1 & & & & & \\
\hline 6 & Small governmentc & -0.10 & -0.14 & -0.20 & 0.18 & -0.42 & 1 & & & & \\
\hline 7 & $\begin{array}{c}\text { Public education } \\
\text { expenditure }\end{array}$ & 0.54 & 0.44 & 0.56 & 0.28 & 0.61 & -0.37 & 1 & & & \\
\hline 8 & Environmental pollution ${ }^{c}$ & -0.11 & -0.18 & -0.06 & -0.02 & 0.07 & 0.38 & 0.22 & 1 & & \\
\hline 9 & Environmental regulation ${ }^{\mathrm{c}}$ & 0.58 & 0.44 & 0.52 & 0.51 & 0.34 & -0.12 & 0.46 & -0.41 & 1 & \\
\hline 10 & Labor regulation $^{\mathrm{c}}$ & -0.33 & -0.30 & -0.25 & -0.32 & -0.14 & -0.22 & -0.23 & -0.07 & -0.34 & 1 \\
\hline 11 & Gender regulation $^{c}$ & 0.26 & 0.21 & 0.15 & 0.31 & 0.02 & -0.03 & 0.22 & 0.10 & 0.15 & -0.18 \\
\hline
\end{tabular}

${ }^{\text {a }}$ Standardised variables. Sample restricted to the sample from column 1 in Table 4. italics: $p<0.05$; bold: $p<0.01$

b Three-year averages

${ }^{\mathrm{c}}$ Measured with five years lag

random effects models. The Fisher test shows that the residuals of the random effects models do not contain a unit root, which supports cointegration.

Columns 1 and 2 show that the overall level of economic freedom and (small) government size do not affect human development. ${ }^{9}$ These results thus do not support the free-market perspective. Conversely, expenditure on publicly financed education (as a percentage of GDP) increase human development, although the effect is only significant at $p<0.10(p=0.068)$. The size of the (standardized) effect is small nor large. The main reason of this positive effect is that public education expenditure increases the educational dimension of human development. If we test the model for the sub dimension of education, the effect is significant at $p<0.01$ and its size is quite large (0.22). This result supports the perfect-market and welfare-state perspectives on good markets. Furthermore, regulation of labor markets significantly decreases human development. Consequently, this finding does not support the welfare-state perspective. If we test the six components of regulation of labor markets (minimum wage, hiring and firing regulations, centralised collective bargaining, hours regulations, mandated cost of worker dismissal, and conscription) separately, we find that hiring and firing regulations, hours regulations, mandated cost of worker dismissal, and conscription have a significant negative effect on human development, whereas centralized collective bargaining has a positive effect (see Appendix Table 8). Finally, gender regulation slightly increases human development, which provides support for the welfare-state perspective, but the size of the standardized effect is very small.

\footnotetext{
${ }^{9}$ As there is overlap between public education expenditure and the size of the government, we did robustness analysis by dropping public education expenditure. However, the results for the size of the government (or any of the other variables) did not change. The reason could be that public education expenditure only counts for a relatively small part of total public expenditure and that small government Fraser Institute also includes fiscal freedom (e.g. top marginal tax rates), and the share of government enterprises and investment.
} 
Table 4 Estimation results ${ }^{\mathrm{a}}$

\begin{tabular}{|c|c|c|c|c|}
\hline & \multicolumn{2}{|c|}{ Human development index } & \multicolumn{2}{|c|}{ Environmental pollution } \\
\hline & 1 & 2 & 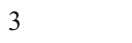 & 4 \\
\hline & RE model & FE model & RE model & FE model \\
\hline Economic freedom & -0.04 & -0.05 & 0.20 & 0.22 \\
\hline (Small) size of government & -0.01 & -0.01 & & \\
\hline Public education expenditure & $0.04^{+}$ & $0.04^{+}$ & & \\
\hline Environmental pollution & $-0.10^{*}$ & $-0.10^{*}$ & & \\
\hline Environmental regulation & & & $-0.18 * *$ & $-0.17 * *$ \\
\hline Labor regulation & $-0.09 * * *$ & $-0.10 * * *$ & & \\
\hline Gender regulation & $0.01 * *$ & $0.01 * *$ & & \\
\hline Political rights & $0.23 *$ & $0.10^{* * *}$ & 0.02 & 0.12 \\
\hline Urbanisation & 0.13 & 0.30 & 0.00 & -0.08 \\
\hline Labor share industry & -0.05 & -0.02 & 0.16 & 0.16 \\
\hline Great circle air distance & 0.10 & & -0.04 & \\
\hline Landlocked & 0.01 & & -0.11 & \\
\hline Temperature & -0.15 & & 0.15 & \\
\hline Post-communist & -0.06 & & 0.11 & \\
\hline Monarchy & -0.03 & & 0.03 & \\
\hline Christian (\%) & 0.00 & & 0.09 & \\
\hline Muslim (\%) & -0.15 & & 0.37 & \\
\hline Non-religious (\%) & 0.00 & & 0.02 & \\
\hline $\mathrm{R}^{2}$ within & 0.63 & 0.64 & 0.32 & 0.33 \\
\hline $\mathrm{R}^{2}$ between & 0.66 & 0.27 & 0.25 & 0.02 \\
\hline $\mathrm{R}^{2}$ overall & 0.58 & 0.30 & 0.30 & 0.06 \\
\hline$P$ value Hausman test & \multicolumn{2}{|c|}{0.154} & \multicolumn{2}{|c|}{0.300} \\
\hline $\mathrm{P}$ value Fisher test of residuals & 0.001 & 0.011 & 0.000 & 0.823 \\
\hline $\mathrm{N}$ observations & 323 & 323 & 400 & 400 \\
\hline $\mathrm{N}$ countries & 35 & 35 & 28 & 28 \\
\hline
\end{tabular}

a+ $\mathrm{p}<0.10 ; * \mathrm{p}<0.05 ; * * \mathrm{p}<0.01 ; * * * \mathrm{p}<0.001$. Standardized coefficients. Robust standard errors

Columns 1-2 show that environmental pollution decreases human development, whereas columns 3-4 show that environmental regulation significantly and substantially reduces environmental pollution. ${ }^{10}$ This suggests that environmental regulations improve human development. This finding once again supports the perfect-market and welfare-state perspectives on good markets, while providing no support for the freemarket view.

\footnotetext{
${ }^{10}$ In columns 3 and 4 we took out the size of government, public education expenditure, labour regulation, and gender regulation and used overall economic freedom (instead of economic freedom corrected for size of government and labour regulation). If we include them, the number of observations decreased from 400 to 216, while all these variables were found to be highly insignificant.
} 
Regarding the control variables, respect for political rights positively affects human development. This is in contrast to previous research showing that political institutions do not positively affect economic development (Barro, 1996).

Table 5 reports the test results for the three sub dimensions of human development. For income and education we used the random effects model (because $p$ value of Hausman test $>0.05$ ) and for life expectancy the fixed effects model (because $p$ value of Hausman test $<0.05$ ). For all three dimensions, we find again no significant effect of economic freedom and (small) size of government. Not surprisingly, we find that public education expenditures mostly stimulates education, whereas environmental pollution mostly harms life expectancy. These results are interesting, because they indicate that the causality runs from institutions to human development. If the causality would run from human development to institutions, the outcomes should have shown that particularly income would increase public education expenditure and decrease environmental pollution, as rich countries can afford more public education and more investments in sustainable production and consumption patterns. The fact that the strongest positive effect from public education expenditure is on education and the strongest negative effect from environmental pollution is on life expectancy suggests otherwise. Overall, we conclude that the estimation results tend to support the perfect-market perspective on good markets more than the welfare-state view, because of the negative effect of regulation of labor markets; albeit that the significant, but small, positive effect of gender regulation lends support for the welfare-state perspective. The free-market perspective is not supported either, as indicated by the lack of significance of economic freedom and size of government, the significant positive effect of gender regulation, and the indirect positive effect of environmental regulation on life expectancy.

\section{Cross-Country Analysis}

A quantitative assessment of the effects of institutional differences on HDI at the country level is presented in Table 6. The numbers represent the observed standardized values of the respective variables in the most recent year for the respective country (standardized with the mean and standard error in the full sample). For example, Nordic countries have relatively high public education expenditure (1.97), high environmental regulation (1.81), low labor market regulation $(-0.20)$, and high gender regulation (0.16) in 2018 in comparison to the sample means of these variables. The effects on HDI can be calculated by multiplying the reported value of the respective variable in Table 6 by its estimated coefficient reported in Table 4. For example, a negative value for labor regulation means a positive effect on the HDI, because labor regulation has a negative effect on the HDI. Not unexpectedly, the four Nordic European countries enjoy, on average, the highest HDI. The Nordic countries have a good performance in public education expenditure, environmental regulation, (relatively low) labor regulation and gender regulation. All four factors have a positive effect on human development. The high public education expenditure is particularly notable, which has a large impact on the educational dimension of human development (see Table 5). The Nordic countries maintain an extensive educational infrastructure from preschool up until post-initial education and 
Table 5 Estimation results for three dimensions of $\mathrm{HDI}^{\mathrm{a}}$

\begin{tabular}{llll}
\hline & 1 & 2 & 3 \\
& Income & Education & Life expectancy \\
\hline Economic freedom & -0.09 & -0.10 & -0.16 \\
(Small) size of government & -0.03 & 0.00 & -0.08 \\
Public education expenditure & 0.09 & $0.22^{*}$ & 0.08 \\
Environmental pollution & $-0.26^{*}$ & -0.17 & $-0.48^{* * *}$ \\
Labor regulation & $-0.20^{* * *}$ & $-0.38^{* * *}$ & $-0.21^{* * *}$ \\
Gender regulation & 0.02 & $0.04 * *$ & 0.02 \\
$\mathrm{R}^{2}$ within & 0.35 & 0.60 & 0.72 \\
$\mathrm{R}^{2}$ between & 0.67 & 0.58 & 0.54 \\
$\mathrm{R}^{2}$ overall & 0.57 & 0.47 & 0.51 \\
$\mathrm{P}$ value Hausman test & 0.153 & 0.402 & 0.000 \\
$\mathrm{P}$ value Fisher test of residuals & 0.000 & 0.000 & 0.001 \\
\hline
\end{tabular}

${ }^{\mathrm{a}+} \mathrm{p}<0.10 ; * \mathrm{p}<0.05 ; * * \mathrm{p}<0.01 ; * * * \mathrm{p}<0.001$. Robust standard errors. Column $1 \& 2$ : Random effects models. Column 3: Fixed effect model. Controlled for all control variables reported in Table 4

training, which is almost exclusively publicly financed. Indeed, higher education institutions do not even charge tuition fees. Comparing the Nordic countries with Continental Europe, the difference in HDI $(1.41-1.27=0.14)$ is explained for more than $50 \%$ by the difference in public education expenditure $((1.97-0.04) * 0.04=0.077)$. In the case of Norway, the legal gender board quotas also contribute to the relatively high HDI. Concluding, although the Nordic economies are characterized by a high degree of government intervention, these regulations stand out in internalizing positive and negative externalities. Therefore, economic policies in the Nordic countries fit well in the neoclassical perspective.

In terms of HDI scores, the Nordic countries are followed by Continental European countries and Other Western, mostly Anglo-Saxon, countries. All countries in these two groups, with the exception of Canada and Ireland, are distinguished by wellfunctioning, flexible labor markets. Quite remarkably, Continental European countries spend less on public education than the Nordic countries.

Southern and Central European countries score similarly on HDI. They all score poorly in terms of the public financing of education. This is precisely the opposite of the Nordic countries. When it comes to the functioning of the labor market, the Southern European countries perform worse than Central European countries because of labor market regulation that shields insiders from outsiders.

There appears to be little to remark upon with respect to the other heterogeneous group of countries, with the exception of the overall poor performance of Mexico and Turkey.

Finally, and interestingly, all of the sample countries for which data was available, with the exception of Russia, display an overall good score on the indicator for environmental regulation. This is due to the increased stringency in environmental regulation over time. 


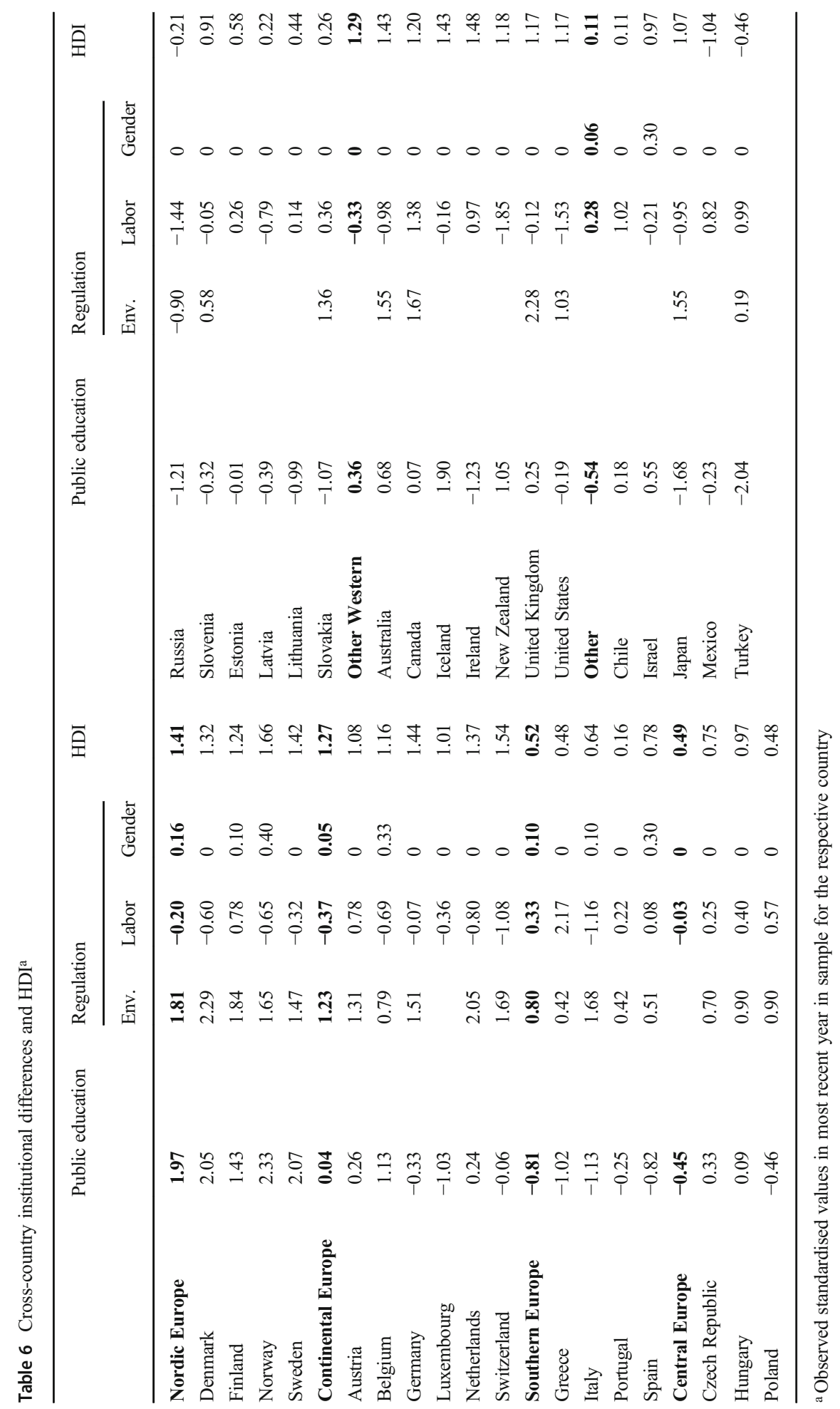




\section{Conclusion and Policy Implications}

Pro-market institutions have been found to be important formal institutions for economic development (Bennett et al., 2017; Justesen, 2008; Murphy, 2016; Spruk \& Kešeljević, 2018) as well as for broader dimensions of development as comprised by the human development index (Özcan \& Bjørnskov, 2011), including education (Aixalá \& Fabro, 2009; Feldmann, 2017; King et al., 2012), health (Stroup, 2007), and the OECD better life index (Nikolaev, 2014). This type of empirical analyses can be theoretically embedded in the pro-market literature that is aligned to the neoliberal free-market perspective. This paper contributes to this literature by comparing this perspective with the neoclassical perfect market perspective and the Keynesian welfarestate perspective. The variables in the empirical analysis reflect this broader framework, as we do not solely test for the relationship between economic freedom and human development, but also test for other institutions that are endorsed by the neoclassical and/or Keynesian views, such as environmental regulation and gender regulation, that are not included in the economic freedom index.

The answer to our research question of which composition of market institutions constitutes a good market for fostering human development is not unequivocal, but of the three concurrent perspectives, the perfect-market perspective of the Neoclassical school comes out best. The policy recommendation of the Neoclassical school that governments should correct market failures to produce socially optimal outcomes is clearly substantiated by this study, particularly in relation to the public financing of education, which is also endorsed by Keynesian thinking, and environmental regulation. The first correction creates a positive externality and cannot be viewed in isolation from a flexible labor market. A well-educated, mobile labor force, supported by postinitial education and retraining programmes is conducive to human development and flourishing. The second correction refers to the internalisation of environmental externalities through regulation. Developing a healthier and sustainable living environment is a policy recommendation that requires no further substantiation.

Interestingly, we also found a positive relationship between human development and regulation of board gender quotas. National welfare states play an integral role in determining women's economic activities, labor market participation, and occupational opportunities (Terjesen et al., 2015). The positive effect of legal gender board quotas suggests that in countries that currently lack this type of regulation, women's talents are being underutilized at the decision-making level, especially at the top level. This is problematic because literature has demonstrated that gender diversity increases innovation (Miller \& del Carmen Triana, 2009). This finding is supported by our results, which show that greater levels of gender equality increase income as well as education and health.

Finally, it is important to highlight three caveats of this study. Firstly, a critical institutional feature of the Neoclassical perspective could not be tested, due to a lack of comparative data. ${ }^{11}$ This pertains to a central tenet of Neoclassical thought, namely the welfare enhancing effect of well-functioning, competitive markets. Of course, there is always an inherent tendency for individual companies in free-market economies to try to prevent competition from other firms to increase their profits. However, for markets

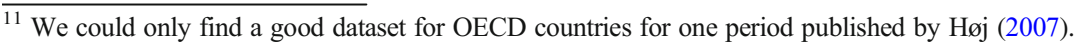


to function properly, market participants must compete with one another. In contrast to free-market economists, who believe that antitrust laws do more harm than good, and, therefore, that we would be better off if we did not have them at all (Friedman, 1999: 7), Neoclassical economists defend the surveillance of market concentration through a competition enforcement policy. Indeed, the literature on competition law and anticartel policies clearly indicates that industries with greater levels of competition experience faster productivity growth, improvement of allocative efficiency and increased innovation. Even the presence of a competition law and enforcement agency functions as a deterrent against anticompetitive behaviour. These previously mentioned factors all positively affect economic growth (Baarsma et al., 2012; Don et al., 2008; OECD, 2014). This lends further support to the perfect-market perspective over the free-market perspective.

Secondly, an important distinguishing feature between the Neoliberal and Keynesian schools of thought is the size of the government. The Fraser-EFW index for government size is, among other things, based on the component 'Transfers and subsidies'. This component discloses the extent of publicly financed social welfare programmes, which may constitute a large percentage of a country's GDP, such as old age pensions and unemployment benefits. In more developed countries, these government-mediated transfers constitute the most important share of GDP, 10 to $25 \%$ (Chang, 2014). ${ }^{12}$ However, a closer examination of this category of transfer payments in the sample countries reveals a multitude of different regulations and arrangements. These range from fully publicly financed to hybrid arrangements involving public means, employeremployee funds and/or private arrangements with investment funds and insurance companies. Hence, it is hard to capture the true economic influence of governments solely by focusing on the size of their budgets relative to GDP. ${ }^{13}$ This may very well explain the lack of significance of this measure in the empirical analyses. Neither the Neoliberal nor Keynesian perspectives have been done justice on this matter.

Third, as we discussed earlier, our results to not prove causality, as we lack proper instrumental variables that prevent a bias due to endogeneity. As socio-economic circumstances may reversely influence a country's adoption of institutions (Berggren, 1999), the results should be interpreted carefully. Although our findings show that the human development is highest in an economy with Neoclassical policies, we do not prove these policies have caused this outcome, as we cannot exclude that human development has reversely increased public education expenditure, environmental regulation and gender equality. However, as we discussed above, the estimation results for the three sub dimensions of human development, income, education and life

\footnotetext{
${ }^{12}$ As pensions are an important component of public spending, one reviewer suggested controlling for the percentage of the population aged over 65 . However, if we added this variable as control variable, the estimation results for small size of government did not change.

${ }^{13}$ Flavin et al. (2014) found that government consumption, welfare spending, decommodification, and labour market regulation all positively affect life satisfaction. There are potentially four major reasons why our results differ. First, the dependent variable in Flavin et al. (2014) was life satisfaction rather than human development. Second, the number of countries (16-21) and observations (42-72) was smaller than in our research (35 countries, 325 observations). Third, Flavin et al. estimated the effect of the various measures of government intervention one by one, rather than simultaneously (as in our research). Fourth, we included some other government regulation variables, such as (other dimensions of) economic freedom, public education expenditures, pollution, and gender regulation. It would be interesting to research which of these four major reasons actually explain the difference in findings.
} 
expectancy, strongly suggest that the causality runs from institutions to human development rather than the reverse. Moreover, also for labor market regulation such inverse causation is less likely.

Acknowledgments The authors thank Reyer Gerlagh, Harry van Dalen, Marjan Hofkes and three anonymous reviewers for their comments on an earlier version of this paper.

Declarations This work was supported by the Templeton World Charity Foundation, Inc. Templeton World Charity Foundation had no involvement in the study design; collection, analysis and interpretation of data; in the writing of the report; and in the decision to submit the article for publication.

Ethical Statement This article does not contain any studies with human participants or animals performed by any of the authors.

Conflict of Interest The authors have no conflict of interest with regard to funding, employment, financial interest or non-financial interest.

\section{Appendix 1 Income, education and health and OECD Better Life Index}

Based on recommendations from Stiglitz et al. (2009), the OECD constructed a so-called "Better Life Index" (BLI) comprising 11 dimensions of well-being: housing, income, jobs, community, education, civic engagement, environment, health, life education, work-life balance, and safety (Balestra et al., 2018; Durand, 2015). Three of these dimensions resemble the income, education and life expectancy dimensions of the HDI. In order to research how the other eight dimensions of the Better Life Index relate to these three dimensions, we performed regression analysis on a sample of 35 OECD members, as well as Brazil, Russia and South Africa. Data was available for the years 2011-2017. For each of the 11 dimensions of well-being, we used normalised values. The results are reported in Table 7.

Table 7 Results of regression analysis ${ }^{\mathrm{a}}$

\begin{tabular}{lllllllll}
\hline & Housing & Jobs & Community & Environment & $\begin{array}{l}\text { Civic } \\
\text { engagement }\end{array}$ & $\begin{array}{l}\text { Life } \\
\text { satisfaction }\end{array}$ & Safety & $\begin{array}{l}\text { Work life } \\
\text { balance }\end{array}$ \\
\hline Income & $0.27 * * *$ & $0.47 * * *$ & 0.03 & $0.18^{* *}$ & 0.07 & $0.17 * *$ & $0.01 * * *$ & 0.07 \\
Education & $0.18^{* * *}$ & $0.26 * * *$ & $0.38^{* * *}$ & $0.42 * * *$ & 0.08 & $0.15^{* *}$ & $0.64 * * *$ & $0.44 * * *$ \\
Health & $0.31 * * *$ & $0.13^{* * * *}$ & $0.37 * * *$ & $0.19 * *$ & $0.35^{* * *}$ & $0.42^{* * *}$ & $0.24 * * *$ & 0.08 \\
$\mathrm{R}^{2}$ & 0.35 & 0.46 & 0.37 & 0.37 & 0.08 & 0.45 & 0.50 & 0.23 \\
\hline
\end{tabular}

a $* p<0.05 ; * * p<0.01 ; * * * p<0.001$

From these results, it can be concluded education and health (which includes life expectancy) significantly add to the prediction of community, civic engagement, safety and work-life balance, in particular. Therefore, the HDI, as measured by OECD, is a better indicator of quality of life than income per capita. 


\section{Appendix 2 Estimation results for six components of labor regulation}

Table 8 Estimation results for components of labor regulation ${ }^{\mathrm{a}}$

\begin{tabular}{lll}
\hline & \multicolumn{2}{l}{ Human development index } \\
\cline { 2 - 3 } \cline { 3 - 3 } & 1 & 2 \\
\hline Economic freedom & RE model & FE model \\
(Small) size of government & -0.03 & -0.04 \\
Public education expenditure & 0.02 & 0.03 \\
Environmental pollution & $0.04^{+}$ & $0.04^{+}$ \\
Minimum wage & $-0.10^{* *}$ & $-0.10^{* *}$ \\
Hiring and firing regulations & 0.00 & 0.00 \\
Centralized collective bargaining & $-0.03^{* * *}$ & $-0.03^{* *}$ \\
Hours regulations & $0.05^{* *}$ & $0.05^{*}$ \\
Mandated cost of dismissal & $-0.03^{* *}$ & $-0.03^{* *}$ \\
Conscription & $-0.06^{* * *}$ & $-0.06^{* *}$ \\
Gender regulation & $-0.06^{* * *}$ & $-0.06^{*}$ \\
\hline
\end{tabular}

$\mathrm{a}_{\mathrm{a}}+p<0.10 ; * p<0.05 ; * * p<0.01$; *** $p<0.001$. Robust standard errors. Controlled for all control variables reported in Table 4.

Open Access This article is licensed under a Creative Commons Attribution 4.0 International License, which permits use, sharing, adaptation, distribution and reproduction in any medium or format, as long as you give appropriate credit to the original author(s) and the source, provide a link to the Creative Commons licence, and indicate if changes were made. The images or other third party material in this article are included in the article's Creative Commons licence, unless indicated otherwise in a credit line to the material. If material is not included in the article's Creative Commons licence and your intended use is not permitted by statutory regulation or exceeds the permitted use, you will need to obtain permission directly from the copyright holder. To view a copy of this licence, visit http://creativecommons.org/licenses/by/4.0/.

\section{References}

Aixalá, J., \& Fabro, G. (2009). Economic freedom, civil liberties, political rights and growth: A causality analysis. Spanish Economic Review, 11(3), 165-178.

Baarsma, B., Kemp, R., van der Noll, R., \& Seldeslachts, J. (2012). Let's not stick together: Anticipation of cartel and merger control in the Netherlands. De Economist, 160(4), 357-376.

Baldwin, R. E. (1992). Are economists' traditional trade policy views still valid? Journal of Economic Literature, 30(2), 804-829.

Barro, R. (1996). Democracy and growth. Journal of Economic Growth, 1(1), 1-27.

Balestra, C., Boarini, R., \& Tosetto, E. (2018). What matters most topPeople? Evidence from the OECD better life index users' responses. Social Indicators Research, 136, 907-930.

Baumol, W. J., \& Oates, W. E. (1988). The theory of environmental policy. Cambridge University Press.

Bennett, D., \& Nikolaev, B. (2017). On the ambiguous economic freedom-inequality relationship. Empirical Economics, 53(2), 717-754. 
Bennett, D. L., Faria, H. J., Gwartney, J. D., \& Morales, D. R. (2017). Economic institutions and comparative economic development: A post-colonial perspective. World Development, 96, 503-519.

Berggren, N. (1999). Economic freedom and equality: Friends or foes? Public Choice, 100(3-4), $203-223$.

Berggren, N., \& Bjørnskov, C. (2019). Regulation and government debt. Public Choice, 178(1-2), 153-178.

Beveridge, W. B. (1942). Social insurance and allied services. HMSO.

Bjørnskov, C., Dreher, A., \& Fischer, J. (2008). Cross-country determinants of life satisfaction: Exploring different determinants across groups in society. Social Choice and Welfare, 30(1), 119-173.

Blanchard, O. S., \& Fischer, S. (1992). NBER macroeconomics annual 1991 (Vol. 6). MIT Press.

Blanchflower, D. G., Oswald, A. J., \& Garrett, M. D. (1990). Insider power in wage determination. Economica, 57(226), 143-170.

Blaug, M. (1978). Economic theory in retrospect (third ed.). Cambridge University Press.

Boyer, G. R., \& Smith, R. S. (2001). The development of the neoclassical tradition in labor economics. Industrial and Labor Relations Review, 54(2), 199-223.

Brue, S. L., \& Grant, R. R. (2007). The evolution of economic thought. Thomson.

Chang, H.-J. (2014). Economics: The user's guide. Penguin Books.

Coase, R. H. (1960). The problem of social cost. Journal of Law and Economics, 3, 1-44.

CPB. (1992). Scanning the future: A long-term scenario study of the world economy 1990-2015. Sdu Publishers.

Cros, J. (1950). Le "néo-libéralisme" et la révision du libéralisme. Thèse droit. Toulouse: Imprimerie Moderne.

Di Tella, R., MacCulloch, R. J., \& Oswald, A. J. (2003). The macroeconomics of happiness. The Review of Economics and Statistics, 85, 809-827.

Don, H., Kemp, R., \& van Sinderen, J. (2008). Measuring the economic effects of competition law enforcement. De Economist, 156(4), 341-348.

Durand, M. (2015). The OECD better life initiative: How's life? And the measurement of well-being. Review of Income and Wealth, 61(1), 4-17.

ver Eecke, W. (1982). Ethics in economics: From classical economics to neoliberalism. Philosophy and Social Criticism, 9, 145-168.

Feldmann, H. (2017). Economic freedom and human capital investment. Journal of Institutional Economics, $13(2), 421-445$.

Flanagan, R. J. (1988). Unemployment as a hiring problem. OECD Economics Studies, 11, 123-154.

Flavin, P., Pacek, A., \& Radcliff, B. (2014). Assessing the impact of the size and scope of government on human well-being. Social Forces, 92, 1241-1258.

Friedman, M. (1962). Capitalism and freedom. University of Chicago Press.

Friedman, M. (1999). The business community's suicidal impulse. Cato Policy Report, 21 (2), 7.

Gwartney, J., Lawson, R., \& Block, W. (1996). Economic freedom in the world, 1975-1995. Fraser Institute.

Gwartney, J., Hall, J., \& Lawson, R. (2017). Economic freedom of the world: 2017 annual report. Retrieved April 19, 2018, from https://www.fraserinstitute.org/studies/economic-freedom-of-the-world-2017annual-report.

Hall, P. A., \& Gingerich, D. W. (2009). Varieties of capitalism and institutional complementarities in the political economy. British Journal of Political Science, 39(3), 449-482.

Hall, P. A., \& Soskice, D. (Eds.). (2001). Varieties of capitalism. Oxford University Press.

Harvey, D. (2005). A brief history of neoliberalism. Oxford University Press.

Hayek, F. A. (1979). Law, legislation and liberty: A new statement of the principles of justice and political economy (Vol. 3). Routledge and Kegan Paul Ltd..

Høj, J. (2007). Competition law and policy indicators for the OECD countries. OECD economics department working papers no. 568. https://www.oecd-ilibrary.org/economics/competition-law-and-policyindicators-for-the-oecd-countries_122166455544.

Jacobs, M. (1997). Sustainability and markets: On the neoclassical model of environmental economics. New Political Economy, 2(3), 365-385.

Justesen, M. K. (2008). The effect of economic freedom on growth revisited: New evidence on causality from a panel of countries 1970-1999. European Journal of Political Economy, 24, 642-660.

Keynes, J.M. (1936/1973). The general theory of employment, interest and money. The Royal Economic Society, London: MacMillan Press.

King, E. M., Montenegro, C. E., \& Orazem, P. F. (2012). Economic freedom, human rights, and the returns to human capital: An evaluation of the Schultz hypothesis. Economic Development and Cultural Change, 61(1), 39-72.

Layard, R. (2005). Happiness - Lessons from a new science. Allen Lane, Penguin Books. 
Lindbeck, A., \& Snower, D.J. (1986). Wage setting, unemployment and insider-outsider relations. The American Economic Review, paper and proceedings, 76, 235-239.

Lindbeck, A., \& Snower, D. J. (1987). Efficiency wage versus insiders and outsider. European Economic Review, 31, 407-416.

Marcuzzo, M. C. (2010). Whose welfare state? Beveridge versus Keynes. In R. E. Backhouse \& T. Nishizawa (Eds.), No wealth but life: Welfare economics and the welfare state in Britain, 1880-1945 (pp. 189-206). Cambridge University Press.

Marshall, A. (1920). (1890). Principles of economics ( $8^{\text {th }}$ ed). Macmillan.

Mayer, T., \& Zignago, S. (2011). Notes on CEPII's distances measures: The GeoDist database. CEPII Working Paper 2011-25.

Miller, T., \& del Carmen Triana, M. (2009). Demographic diversity in the boardroom: Mediators of the board diversity-firm performance relationship. Journal of Management Studies, 46(5), 755-789.

Murphy, R. H. (2016). Economic freedom of North America at state borders. Journal of Institutional Economics, 12(4), 885-893.

Nikolaev, B. (2014). Economic freedom and quality of life: Evidence from the OECD's your better life index'. Journal of Private Enterprise, 29(3), 61-96.

OECD (2014). Factsheet on how competition policy affects macro-economic outcomes, http://www.oecd.org/ daf/competition/2014-competition-factsheet-iv-en.pdf.

Ovaska, T., \& Takashima, R. (2006). Economic policy and the level of self-perceived well-being: An international comparison. Journal of Socio-Economics, 35, 308-325.

Özcan, B., \& Bjørnskov, C. (2011). Social trust and human development. The Journal of Socio-Economics, 40, 753-762.

Pacek, A., \& Radcliff, B. (2008). Welfare policy and subjective well-being across nations: An individual-level assessment. Social Indicators Research, 89, 179-191.

Pesaran, M. H. (2007). A simple panel unit root test in the presence of cross-section dependence. Journal of Applied Econometrics, 22, 265-312.

Pigou, A. C. (1932). The economics of welfare (4th ed.). Macmillan.

Pissarides, C. A. (1990). Equilibrium unemployment theory. Basil Blackwell.

Polemis, M., \& Stengos, T. (2020). The impact of state aid on economic growth. Economics Bulletin, 40(2), 1083-1090.

Ruseski, J. E., \& Maresova, K. (2014). Economic freedom, sport policy, and individual participation in physical activity: An international comparison. Contemporary Economic Policy, 32(1), 42-55.

Ryan, A. (1993). Liberalism. In R. E. Goodin \& P. Pettit (Eds.), A companion to contemporary political philosophy (pp. 291-311). Blackwell.

Sandmo, A. (2011). Economics evolving. A history of economic thought. Princeton University Press.

Schumpeter, J. A. (1976). Capitalism, socialism and democracy (5th ed.). George Allen \& Unwin.

Sen, A. K. (1984). Resources, values and development. Blackwell.

Skidelsky, R., \& Skidelsky, E. (2012) How much is enough. The love of money, and the case for the good life. London: Allen lane.

Spruk, R., \& Kešeljević, A. (2018). Economic freedom and growth across German districts. Journal of Institutional Economics, 14(4), 739-765.

Stigler, G. J. (1971). The theory of economic regulation. Bell Journal of Economics and Management Science, 2, 3-21.

Stiglitz, J., Sen, A., \& Fitoussi, J.P. (2009). The measurement of economic performance and social progress revisited: Reflection and overview. Commission on the Measurement of Economic Performance and Social Progress, Paris, 1-65.

Stroup, M. D. (2007). Economic freedom, democracy, and the quality of life. World Development, 35(1), 5266.

Tabellini, G. (2010). Culture and institutions: Economic development in the regions of Europe. Journal of the European Economic Association, 8(4), 677-716.

Terjesen, S., Aguilera, R. V., \& Lorenz, R. (2015). Legislating a woman's seat on the board: Institutional factors driving gender quotas for boards of directors. Journal of Business Ethics, 128, 233-251.

Thorsen, D.E. (2009). The neoliberal challenge. What is neoliberalism? Oslo, University of Oslo, Department of Political Science, http://folk.uio.no/daget/neoliberalism2.pdf.

UNDP (United Nations Development Program). (2020). Human development report 2020. http://hdr.undp. org/en/2020-report.

Whitley, R. (1999). Divergent capitalisms: The social structuring and change of business systems. Oxford University Press. 
Witt, M. A., Kabbach de Castro, L. R., Amaeshi, K., Mahroum, S., Bohle, D., \& Saez, L. (2018). Mapping the business systems of 61 major economies: A taxonomy and implications for varieties of capitalism and business systems research. Socio-Economic Review, 16(1), 5-38.

Publisher's Note Springer Nature remains neutral with regard to jurisdictional claims in published maps and institutional affiliations.

\section{Affiliations}

\section{Johan Graafland ${ }^{1} \cdot$ Harmen Verbruggen ${ }^{2}$}

1 Department of Economics, Department of Philosophy, Center, Tilburg Sustainability Center, Tilburg University, P.O. Box 90153, 5000 LETilburg, the Netherlands

2 Department of Spatial Economics, School of Business and Economics, Vrije Universiteit Amsterdam, De Boelelaan 1105, 1081 HV Amsterdam, The Netherlands 